\title{
GAMBARAN KEPATUHAN MENGGUNAKAN MASKER SAAT PRAKTIKUM MAHASISWA DI KLINIK GIGI JURUSAN KEPERAWATAN GIGI MANADO TAHUN 2018
}

\author{
Novarita Mariana Koch ${ }^{1)}$, I Ketut Harapan ${ }^{2)}$ \\ ${ }^{1,2)}$ Jurusan Keperawatan Gigi Poltekkes Kemenkes Manado Jl. R.W. Mongisidi Malalayang Manado
}

Email : kochnovarita@gmail.com

\begin{abstract}
ABSTRAK
Prinsip penting dari keberadaan institusi pelayanan kesehatan berkualitas yaitu perlindungan bagi pasien, tenaga kesehatan, tenaga pendukung dan komunitas masyarakat disekitarnya dari penularan infeksi. Salah satu cara yang dapat dilakukan yaitu mengenakan alat pelindung diri yaitu masker. Masker yang menutupi mulut dan hidung dapat mengurangi terhirupnya partikel aerosol juga melindungi terkontaminasinya membran mukosa dari hidung dan mulut. Alat pelindung diri yang digunakan harus sesuai dengan potensi bahaya dan resiko pekerjaannya sehingga efektif melindungi pekerja sebagai penggunanya. Tujuan penelitian ini yaitu untuk mengetahui bagaimana kepatuhan menggunakan masker pada saat praktikum mahasiswa di klinik gigi Jurusan Keperawatan Gigi Manado.

Penelitian ini dilakukan dengan metode deskriptif. Penelitian dilaksanakan pada bulan Juli tahun 2018 di klinik gigi Jurusan Keperawatan Gigi Manado dengan jumlah populasi sebanyak 48 mahasiswa yang praktek di klinik gigi, sampel penelitian yaitu total populasi. Instrument penelitian menggunakan format check list terstruktur. Data diperoleh, ditabulasi dan disajikan dalam bentuk tabel distribusi frekuensi, penelitian ini bertujuan untuk mengetahui tingkat kepatuhan terhadap penggunaan masker pada mahasiswa tingkat II Jurusan Keperawatan Gigi Poltekkes Manado.

Hasil penelitian menunjukkan bahwa kepatuhan penggunaan masker pada mahasiswa tingkat II jurusan keperawatan gigi Poltekkes Manado bahwa dari 48 responden terdapat 26 responden $(54,1 \%)$, dengan kategori kepatuhan kurang baik.
\end{abstract}

Kata Kunci : Alat Pelindung Diri, Masker, Kepatuhan

\begin{abstract}
An important principle of the existence of quality health care institutions is protection for patients, health workers, support staff and surrounding communities from infection. One way that can be done is to wear personal protective equipment, namely masks. Masks that cover the mouth and nose can reduce inhalation of aerosol particles and also protect the mucous membrane contamination of the nose and mouth. Personal protective equipment used must be in accordance with the potential hazards and risks of work so that it effectively protects workers as users. The purpose of this study was to find out how compliance using a mask when practicing students in the dental clinic Manado Dental Nursing Department.

This research was conducted by descriptive method. The study was conducted in July 2018 in the dental clinic of the Manado Dental Nursing Department with a population of 48 students practicing in the dental clinic, the research sample being the total population. The research instrument uses a structured check list format. Data obtained, tabulated and presented in the form of a frequency distribution table, this study aims to determine the level of adherence to the use of masks in the second year students of the Department of Dental Nursing Poltekkes Manado.
\end{abstract}


The results showed that the compliance of the use of masks in the second level students majoring in dental nursing in Manado Poltekkes that of 48 respondents there were 26 respondents $(54.1 \%)$, with poor adherence category.

\section{Keywords: Personal Protective Equipment, Mask, Compliance}

\section{PENDAHULUAN}

Keadaan sehat adalah kehendak semua pihak, tidak hanya didominasi oleh perorangan akan tetapi juga harus dimiliki oleh kelompok dan bahkan oleh masyarakat. ${ }^{1}$ Berbagai kemungkinan yang bersifat negatif atau kurang menguntungkan dapat terjadi pada klien meskipun telah dilakukan upaya-upaya untuk menghindarinya. ${ }^{2}$ Adanya perlindungan diri bagi tenaga kesehatan maupun klien merupakan suatu keadaan yang sangat penting. Menurut Halanjur ,2018, Alat pelindung diri yang digunakan harus sesuai dengan potensi bahaya dan resiko pekerjaan. $^{3}$ Adanya masker yang merupakan salah satu pelindung wajah yaitu masker yang dapat mencegah kontak antara droplet dari mulut dan hidung petugas yang mengandung mikroorganisme ke pasien dan mencegah kontak droplet/darah/cairan tubuh pasien kepada petugas. ${ }^{4}$ WHO mencatat tahun 2004 kasus infeksi nosokomial di dunia berupa penularan hepatitis B sebanyak 66 kasus, hepatitis C sebanyak 16.000 dan 10.000 kasus penularan HIV. ${ }^{5}$

Target WHO 2020 salah satunya adalah meningkatkan jumlah pelayanan kesehatan yang kompeten untuk mengenali dan mengurangi risiko dari transmisi penyakit menular dilingkungan pelayanan kesehatan gigi dan mulut. ${ }^{6}$

Adanya resiko yang ditimbulkan jika tidak memiliki kepatuhan menggunakan masker maka petugas kesehatan harus menunjukkan perilaku positif untuk mencegah resiko yang mungkin terjadi. Tujuan penelitian ini yaitu untuk mengetahui bagaimana kepatuhan menggunakan masker pada saat praktikum mahasiswa di klinik gigi Jurusan Keperawatan Gigi Manado
Jenis penelitian yang akan digunakan yaitu penelitian survei deskriptif untuk mengetahui kepatuhan mahasiswa tentang penggunaan masker saat praktikum di klinik gigi jurusan keperawatan gigi Manado, jenis penelitian ini mendeskripsikan atau menggambarkan suatu fenomena yang terjadi di masyarakat. ${ }^{7}$

Waktu penelitian 31 Juli-2 Agustus 2018, tempat penelitian klinik gigi jurusan keperawatan gigi Poltekkes Manado, Instrument penelitian berupa pengamatan dan format Check list untuk mengukur kepatuhan mahasiswa dalam penggunaan masker.

\section{HASIL DAN PEMBAHASAN}

\section{HASIL}

1. Distribusi Responden Berdasarkan Jenis Kelamin

Responden yang berjenis kelamin laki-laki berjumlah 4 orang $(8,3 \%)$ dan jenis

kelamin perempuan berjumlah 44 orang $(91,6 \%)$.

2. Responden Menurut Golongan Umur Responden yang berumur 19-22 tahun berjumlah 46 orang $(95,8 \%)$, umur $23-26$ tahun berjumlah 2 orang $(4,1 \%)$.

3. Distribusi Responden Menurut Kategori Tindakan Kepatuhan

Responden dengan tindakan baik sebanyak 10 responden $(20,8 \%)$, tindakan cukup sebanyak 12 responden $(25 \%)$ dan tindakan kurang sebanyak 26 responden $(54,1 \%)$. 


\section{PEMBAHASAN}

Banyak faktor resiko yang terdapat di rumah sakit maupun fasilitas pelayanan kesehatan lain yang menyebabkan terjadinya resiko klinik. Faktor resiko tersebut sulit dihilangkan atau dieliminer hanya bisa dikelola sedemikian rupa sehingga resiko klinik yang terjadi dapat dikendalikan dan ditekan sekecil mungkin. ${ }^{2}$ Faktor resiko yang mungkin terjadi dapat dicegah antara lain dengan menggunakan alat pelindung diri masker. Menurut Mulyanti dan Putri (2012) masker digunakan untuk melindungi dokter gigi dan perawat gigi dari percikan yang berasal dari henpis berkecepatan tinggi yang digunakan bila sebuah gigi dipreparasi atau menggunakan skeler ultrasonik. Masker yang menutupi mulut dan hidung dapat mengurangi terhirupnya partikel aerosol juga melindungi terkontaminasinya membran mukosa dari hidung dan mulut. ${ }^{8}$

Kepatuhan tentang penggunaan masker pada mahasiswa tingkat II yang melakukan praktek di klinik gigi paling banyak berada pada kriteria kurang yaitu sebanyak 54,1 \%) dan resonden yang berada pada kriteria baik 10 responden $(20,8 \%)$ dan tindakan cukup sebanyak 12 responden $(25 \%)$. Dari hasil penelitian ini terlihat kepatuhan mahasiswa terhadap penggunaan masker masih kurang. Mahasiswa yang sudah memiliki pengetahuan tentang masker yang telah dipelajari sebelum melakukan praktek di klinik gigi, namun pada saat dilakukan penelitian tentang penggunaan alat pelindung diri khususnya masker didapati mahasiswa yang praktek di klinik gigi kurang patuh terhadap penggunaan masker, artinya bahwa mahasiswa menyepelehkan alat pelindung diri dalam hal ini masker. Kelalaian mahasiswa yang kurang menyadari tentang bahaya yang dapat ditimbulkan akibat penggunaan masker yang kurang tepat saat melakukan praktikum di klinik gigi, mahasiswa hanya terfokus pada penyelesaikan target sesuai dengan waktu yang sudah ditentukan sehingga mahasiswa bekerja secara terburu-buru tanpa memikirkan resiko serta melupakan tentang pentingnya penggunaan masker saat praktikum di klinik gigi.

Hasil penelitian oleh Perwitasari dan Anwar (2006) bahwa berdasarkan penggunaan APD, lebih dari $40 \%$ petugas beresiko tinggi terinfeksi penyakit yang berbahaya. ${ }^{9}$ Penelitian oleh Harlan dan Paskarini (2014) juga yang berjudul faktor yang berhubungan dengan perilaku penggunaan APD pada petugas laboratorium Rumah Sakit PHC Surabaya bahwa hanya 40\% responden yang mempunyai perilaku penggunaan APD baik. Perhatian untuk bahaya dan resiko kerja perlu ditanamkan terutama pada petugas kesehatan sebagai bagian dari prinsip hidup sehat menggunakan alat pelindung diri antara lain masker. Sangat sederhana tetapi terkadang masker dilupakan dan diremehkan. Harus disikapi bahwa mahasiswa yang bekerja di klinik memperhatikan penggunaan masker demi keselamatan bersama bukan hanya untuk pribadinya tetapi untuk pasien yang ditangani. ${ }^{10}$. Penelitian oleh Romadhoni dan Widowati (2017) bahwa penerapan kewaspadaan standart yang kurang akan menimbulkan konsekwensi kesehatan yang tidak menguntungkan yang diderita oleh banyak orang sebagai akibat kesalahan medis. ${ }^{11}$ Kebiasan dapat mempengaruhi kerja karena resiko kerja tergantung dari patuhnya petugas dalam menangani pasien atau kliennya. Mulyani dan Putri (2015) menyatakan bahwa konsentrasi paling besar dari mikroorganisme adalah kurang lebih $61 \mathrm{~cm}$, tempat dimana dokter gigi dan perawat gigi biasanya berada. ${ }^{8}$ Masker yang merupakan pelindung wajah yang dapat mencegah kontak antara droplet dari mulut dan hidung petugas yang mengandung mikroorganisme ke pasien dan mencegah kontak droplet/ darah/ cairan tubuh pasien kepada petugas. ${ }^{4}$ Menggunakan alat pelindung diri masker menjadi salah satu bentuk perlindungan bagi diri dan orang lain agar tehindar dari resiko yang dapat menyebabkan kerugian bagi sipetugas maupun pasien. ${ }^{2}$ Pemahaman tentang konsep dan pengertian resiko klinik dilandasi dan sejalan dengan pemahaman tentang sifat dasar, karakteristik, fungsi dan aktifitas pelayanan yang terjadi di rumah sakit, puskesmas, klinik dan sejenisnya. Bagaimana petugas kesehatan menunjukkan perilaku patuhnya terhadap penggunaan masker sebagai bagian dari alat pelindung diri untuk memberikan wujud penegakan disiplin diri dan orang lain untuk hidup sehat, karena menurut kamus besar bahasa Indonesia, patuh merupakan penurut 
adalah suka menurut perintah, taat pada perintah, sedangkan kepatuhan adalah perilaku sesuai aturan dan berdisiplin. Patuh adalah sikap positif individu yang ditunjukan dengan adanya perubahan secara berarti sesuai dengan tujuan yang ditetapkan. ${ }^{\mathbf{2}}$

\section{KESIMPULAN DAN SARAN}

\section{KESIMPULAN}

Kesimpulan dari penelitian ini bahwa mahasiswa yang tidak patuh dalam penggunaan Alat pelindung Diri khususnya masker lebih banyak dari pada yang patuh yaitu dari 48 responden didapati bahwa mahasiswa dengan tindakan kurang sebanyak 26 responden $(54,1 \%)$.

\section{SARAN}

Saran yang dapat diberikan yaitu :

1. Mahasiswa jurusan keperawatan gigi yang melakukan praktek di klinik gigi harus lebih memperhatikan penggunaan Alat Perlindungan Diri khususnya masker pada saat berhadapan dengan pasien. Hal ini bertujuan untuk menghindari terjadinya penularan penyakit dari atau kepada orang lain.

2. Petugas klinik, dosen untuk lebih memberi penegasan dalam pengawasan penggunaan Alat pelindung diri khususnya masker dan memberikan sanksi bagi mahasiswa yang tidak patuh dalam penggunaan Alat pelindung diri

3. Bagi peneliti selanjutny dapat menjadi acuan untuk penelitian selanjutnya tentang alat peindung diri.

\section{DAFTAR PUSTAKA}

1. Taufik, M. 2007. Prinsip-Prinsip Promosi Kesehatan Dalam Bidang Keperawatan Untuk Perawat Dan Mahasiswa Keperawatan. CV. Infomedika. Jakarta.

2. Menap, H. 2018. Manajemen Resiko Klinik Bangsal Keperawatan Rumah Sakit dan
Keselamatan Pasien. Husada Mandiri. Yogyakarta

3. Halanjur, U. 2018. Promosi Kesehatan Di Tempat Kerja. Wineka Media. Malang.

4. Nursalam dan Kurniawati, N.D. 2007. Asuhan Keperawatan Pada Pasien Terinfeksi HIV/AIDS. Salemba Medika. Jakarta.

5. Suharto dan Sumirar, R. 2016. Hubungan Pengetahuan Dan Sikap Perawat Dengan Tindakan Pencegahan Infeksi Di Ruang ICU Rumah Sakit. Jurnal Riset Hesti Medan Vol.1, No 1 Juni 2016.

6. Kementerian Kesehatan RI. 2012. Standar Pencegahan dan Pengendalian Infeksi Pelayanan Kesehatan Gigi dan Mulut di Fasilitas Pelayanan Kesehatan. Direktorat Bina Upaya Kesehatan. Jakarta.

7. Notoatmodjo, S. (2002). Metode Penelitian Kesehatan. Rineke cipta. Jakarta.

8. Mulyanti, S dan Putri, M.H. 2015. Pencegahan Infeksi Silag Di Klinik Gigi. EGC. Jakarta

9. Perwitasari, D dan Anwar, A. 2006. Tingkat Resiko Pemakaian Alat Pelindung Diri Dan Higiene Petugas Di Laboratorium Klinik RSUPN Ciptomangunkusumo, Jakarta. Jurnal Ekologi Kesehatan Vol 5 No 1 April 2006:380-384

10. Harlan, A.N dan Paskarini, I. 2014. Faktor Yang Berhubungan Dengan Perilaku Penggunaan APD Pada Petugas Laboratorium Rumah Sakit PHC Surabaya. The Indonesian Journal of Occupational Safety, Health and Environment, Vol.1 JanApril 2014:107-119

11. Romadhoni, S dan Widowati, E. 2017. Penerapan Kewaspadaan Standar Sebagai Upaya Pencegahan Bahaya Biologi Pada tenaga Keperawatan. Higeia Journal Of Public Health Research And Development. Higeia 1 (4) (2017).

12. Taufik, M. 2007. Prinsip-Prinsip Promosi Kesehatan Dalam Bidang Keperawatan Untuk Perawat Dan Mahasiswa Keperawatan. CV. Infomedika. Jakarta. 